\title{
ENTREPRENEUR
}

Jurnal Bisnis Manajemen Dan Kewirausahaan

Program Studi Manajemen Fakultas Ekonomika dan Bisnis Universitas Majalengka

Published every January and July e-ISSN : (Proses), p-ISSN: 2723-1941

Available online https://ejournal.unma.ac.id/index.php/entrepreneur

\section{Pengaruh Motivasi Hedonis, Browsing dan Gaya Hidup Berbelanja Terhadap Pembelian Impulsif Di Online Shop (Studi Pada Mahasiswa Universitas Majalengka).}

\author{
R. Neny Kusumadewi \\ Fakultas Ekonomika dan Bisnis Uiversitas Majalengka \\ email : kusumadewi.neny@gmail.com
}

\begin{abstract}
This study aims to determine how the influence of Hedonic Motivation, Browsing and Shopping Lifestyle on Impulsive Purchases at the Online Shop of Majalengka University students, either partially or simultaneously.

The research method used is a survey method with descriptive and verification approaches. The sample used in this study were 100 respondents, the test instruments used in this study were validity and reliability tests. The data analysis used in this research is classical assumptions, multiple regression analysis, coefficient of determination, and hypothesis testing. For the partial test using the t test and test simultaneously using the F test.

The results showed that hedonic motivation was in the high category, high category browsing, high shopping lifestyle, and high category impulsive buying. Partially hedonic motivation has a positive and significant effect on impulsive buying, browsing has a positive and significant effect on impulsive buying, and the shopping lifestyle has a positive and significant effect on impulsive buying. Simultaneously, hedonic motivation, browsing and shopping lifestyle have a positive and significant effect on impulsive buying. This means that the higher the level of hedonic motivation, browsing and shopping lifestyle, the higher the level of consumer impulse purchases at the online shop.
\end{abstract}

Keywords:

Hedonic Motivation;Browsing;Shopping Lifestyle;and Impulsive Buying 


\section{ENTREPRENEUR}

Jurnal Bisnis Manajemen Dan Kewirausahaan

Program Studi Manajemen Fakultas Ekonomika dan Bisnis Universitas Majalengka

Published every January and July e-ISSN : (Proses), p-ISSN: 2723-1941

Available online https://ejournal.unma.ac.id/index.php/entrepreneur

\section{PENDAHULUAN}

Teknologi informasi saat ini berkembang semakin pesat dengan adanya jaringan internet. Internet telah menciptakan sebuah dunia ekonomi baru yang menimbulkan dampak pada beberapa aspek kehidupan, tidak terkecuali perkembangan dunia bisnis dan pemasaran. Jangkauan internet yang luas sudah banyak dimanfaatkan orang sebagai media pemasaran dan bisnis. Hal ini membuat praktik bisnis melalui internet mempunyai banyak keuntungan baik bagi perusahaan maupun bagi konsumen.

Internet menjadi media untuk mendapatkan informasi yang sifatnya sangat luas dan tidak terbatas. Melalui situs-situs website internet, manusia bisa mengakses informasi sampai penjuru dunia. Pengguna internet di Indonesia mengalami peningkatan yang cukup pesat, dan hal ini pun akan terus meningkat tiap tahunnya. Ini menjadi salah satu alasan mengapa banyak perusahaan telekomunikasi berlombalomba untuk berbisnis di Indonesia. Pengguna internet yang terus bertambah bersama dengan perkembangan teknologi dapat menggeser pandangan masyarakat dalam memandang suatu bisnis terutama pada penjualan dan promosi. Internet merupakan salah satu produk jasa yang sangat mudah dioperasikan dan dapat digunakan sepanjang waktu. Penggunaan internet sudah menjadi sebuah gaya hidup bagi sebagian penduduk di dunia, tidak terkecuali penduduk Indonesia. Hal ini jelas menjadi sebuah potensi bisnis yang sangat menjanjikan. $\begin{array}{rrr}\text { Perkembangan } & \text { teknologi } & \text { internet } \\ \text { telah mengubah } & \text { berbagai } & \text { aspek }\end{array}$ kehidupan termasuk perilaku konsumen. Kebutuhan untuk mengaktualisasikan diri di dunia maya berdampak secara tidak langsung maupun secara langsung terhadap perilaku konsumen dalam membeli dan mengkonsumsi produk. Perkembangan pengguna internet tersebut mendorong terjadinya suatu potensi besar terciptanya online shop. Oleh sebab itu peluang untuk menjalankan bisnis online semakin terbuka bagi pelaku bisnis di Indonesia.

Perkembangan online shop menjadi begitu pesat dipicu oleh inovasi yang makin memanjakan konsumen. Tidak dipungkiri pertumbuhan positif online shop di Indonesia, membuat perubahan pola belanja masyarakat yang semakin bergeser ke arah elektronik atau online shopping. Keberadaan online shop telah mempengaruhi perilaku belanja masyarakat, di mana masyarakat lebih sering berbelanja online dibanding berbelanja di toko offline.

Jumlah konsumen yang berkunjung pada e-Commerce yang ada di Indonesia menurut 1)Teknologi.id hingga kuartal pertama tahun 2018 Lazada masih mampu mempertahankan posisinya di puncak sebagai marketplace dengan pengunjung terbanyak yaitu mencapai 117,6 juta. Angka tersebut diperoleh berdasarkan studi terbaru Peta $e$ Commerce iPrice. Diposisi kedua ada Tokopedia dengan jumlah pengunjung mencapai 117,3 juta. Diposisi ketiga ada Bukalapak dengan 93,6 juta pengunjung. Posisi keempat ditempati oleh Blibli dengan pengunjung berjumlah 45,9 juta. 


\section{ENTREPRENEUR}

Jurnal Bisnis Manajemen Dan Kewirausahaan

Program Studi Manajemen Fakultas Ekonomika dan Bisnis Universitas Majalengka

Published every January and July e-ISSN : (Proses), p-ISSN: 2723-1941

Available online https://ejournal.unma.ac.id/index.php/entrepreneur

Sedangkan Shopee menempati posisi kelima dengan jumlah pengunjung sebanyak 34,5 juta. Setelah Shoppe diurutan keenam ditempati oleh JD.id dengan pengunjung 13,2 juta. Diurutan ketujuh ada Bhineka dengan pengunjung mencapai 7,4 juta. Selanjutnya ada Elevania diposisi kedelapan denganpengunjung sebanyak 6,3 juta. Zalora menempati posisi sembilan dengan 5,2 juta pengunjung. Dan diposisi terakhir ditempati oleh MatahariMall dengan pengunjung sebanyak 4 juta.

Konsumen memperoleh banyak manfaat dengan berbelanja secara online, yaitu lebih nyaman, produk lebih beragam, transaksi lebih cepat, harga lebih murah, tanpa antrian, rahasia konsumen terlindungi, dan dapat menghemat waktu, tenaga maupun biaya. Selain itu, belanja secara online juga memiliki kelemahan, yaitu minimnya bantuan saat berbelanja dimana konsumen tidak dapat melakukan kontak fisik secara langsung dengan penjual, produk tidak bisa diraba dan dicoba sehingga tidak sedikit konsumen yang merasa kecewa dengan barang yang dibeli.

Tingginya tingkat persaingan baik untuk produk sejenis maupun produk berbeda yang menawarkan kemudahan mendapatkan informasi tentang barang dan jasa membuat konsumen merasa suka berbelanja untuk memenuhi kebutuhan akan barang yang belum dimilikinya. Seseorang yang melihat koleksi terbaru pada online shop cenderung merasa ingin memiliki barang tersebut walaupun sebelumnya tidak memliki rencana untuk belanja. Hal ini memicu timbulnya pembelian impulsif. Banyak faktor yang dapat membuat konsumen melakukan pembelian tidak terencana atau pembelian impulsif di online shop. Seperti diketahui banyak barang kebutuhan seperti fashion, elektronik, alat olahraga yang ditawarkan di internet dan menawarkan kemudahan dalam cara berbelanja dan pembayaran. Dengan demikian, hal tersebut sangat memiliki potensial untuk terjadinya pembelian impulsif secara online.

Menurut ${ }^{2}$ Christina W. Utami (2010:51) dalam ${ }^{3)}$ Dayang A. Kosyu dkk (2014) mengatakan bahwa pembelian impulsif adalah pembelian yang terjadi ketika konsumen melihat produk atau merek tertentu, kemudian konsumen menjadi tertarik untuk mendapatkannya, biasanya karena adanya rangsangan yang menarik dari toko tersebut. Ada beberapa faktor yang membuat seorang konsumen melakukan pembelian impulsif pada online shop, salah satunya adalah adanya rangsangan motivasi hedonis pada diri konsumen.

Motivasi hedonis adalah salah satu faktor yang dapat mempengaruhi pembelian impulsif pada Online Shop. Penelitian yang dilakukan oleh ${ }^{4)}$ Toto Pribadi dan Winarso (2015) menunjukkan bahwa konsumen membeli produk online hanya untuk mencari kesenangan dan kepuasan dari belanja, tanpa memikirkan kegunaan produk tersebut.

Menurut ${ }^{2)}$ Christina W. Utami (2010:47) motivasi hedonis adalah motivasi konsumen untuk berbelanja karena merupakan suatu kesenangan tersendiri sehingga tidak memperhatikan manfaat dari produk yang dibeli. 


\section{ENTREPRENEUR}

Jurnal Bisnis Manajemen Dan Kewirausahaan

Program Studi Manajemen Fakultas Ekonomika dan Bisnis Universitas Majalengka

Published every January and July e-ISSN : (Proses), p-ISSN: 2723-1941

Available online https://ejournal.unma.ac.id/index.php/entrepreneur

Faktor lingkungan berbelanja ternyata juga dapat memunculkan sifat hedonis. Sifat hedonis pada konsumen yang cenderung membeli tanpa mengutamakan prioritas berbelanja sesuai dengan kebutuhannya. Motivasi hedonis akan terjadi ketika seseorang melihat barangbarang yang dijual pada online shop, terlebih online shop sering menawarkan barang-barang model terbaru, berkualitas, harga yang terjangkau, promo bahkan kemudahan dalam hal pembayaran yang mengakibatkan seseorang berbelanja berlebihan untuk memenuhi kepuasan tersendiri. Dengan ini konsumen sangat mudah untuk memilih barang-barang yang diinginkan dengan cara browsing.

Browsing merupakan faktor selanjutnya yang menyebabkan pembelian impulsif. Penelitian yang dilakukan oleh ${ }^{4)}$ Toto Pribadi dan Winarso (2015) membuktikan bahwa semakin lama konsumen melakukan browsing, semakin besar pula kemungkinan terjadinya pembeliam impulsif pada Online Shop.

Browsing atau surfing yaitu kegiatan "berselancar" di internet. Menurut ${ }^{5)}$ Iyer (1989) dalam ${ }^{6)}$ Gultekin dan Ozer (2012) konsumen lebih banyak mengalokasikan waktu mereka untuk browsing sehingga dapat meningkatkan jumlah pembelian mereka. Pencarian informasi dapat terjadi melalui pencarian sengaja maupun tidak sengaja. Pada umumnya seorang konsumen akan mendapat suatu iklan, atau informasi barang yang sedang dipromosikan sehingga secara tidak sengaja akan menambah informasi terhadap suatu produk yang akan dibelinya kemudian hari, sedangkan ketika seseorang konsumen berada pada tahap pengambilan keputusan ia mencari informasi lebih dalam lagi.

Hal tersebut lebih mempermudah seorang konsumen untuk melakukan pencarian informasi melalui browsing. Konsumen yang gemar berbelanja memiliki kecenderungan lebih besar untuk mencari informasi tentang produk atau jasa yang mereka inginkan dengan cara browsing. Semakin sering seorang konsumen melakukan browsing pada online shop akan menyebabkan konsumen tersebut melakukan pembelian impulsif. Selain itu, ada satu rangsangan lagi yang menyebabkan seorang konsumen melakukan pembelian impulsif terutama pada online shop, yaitu adanya gaya hidup berbelanja seorang konsumen.

Gaya hidup berbelanja merupakan faktor lain yang menyebabkan terjadinya pembelian impulsif. Penelitian yang dilakukan oleh ${ }^{4)}$ Toto Pribadi dan Winarso (2015) membuktikan bahwa gaya belanja merupakan suatu yang mengarah kepada pola konsumsi yang mencerminkan bahwa konsumen berbelanja bukan karena kebutuhan tetapi hanya untuk menunjukan status sosial mereka.

Kebutuhan konsumen berpengaruh pada gaya hidup atau lifesyle. Banyaknya mode fashion atau barang lain yang baru bermunculan membuat konsumen ingin selalu mengikuti perkembangannya. Menurut ${ }^{7)}$ E. Japarianto dan S. Sugiharto (2011), gaya hidup berbelanja adalah gaya hidup seseorang untuk 


\section{ENTREPRENEUR}

Jurnal Bisnis Manajemen Dan Kewirausahaan

Program Studi Manajemen Fakultas Ekonomika dan Bisnis Universitas Majalengka

Published every January and July e-ISSN : (Proses), p-ISSN: 2723-1941

Available online https://ejournal.unma.ac.id/index.php/entrepreneur

mengalokasikan waktu dan uang untuk berbagai kebutuhan dan keinginan.

Penelitian ini dilakukan di Universitas Majalengka dan sebagai respondennya adalah mahasiswa, karena banyak mahasiswa Universitas Majalengka yang membuka usaha online shop, selain itu banyak dari mahasiswa yang menjadi langganan di berbagai online shop terutama pada produk fashion. Hal ini dikarenakan pembelian secara online sangatlah mudah dan mempersingkat waktu pembeli tanpa harus pergi ke toko secara langsung. Online shop sangat sesuai bagi mahasiswa dengan jadwal kuliah yang padat serta tidak adanya waktu yang tepat untuk belanja secara langsung bertatap muka dengan penjual di tokokonvensional. Selain itu, mahasiswa juga dapat memilih produk yang mereka inginkan serta harga yang sesuai dengan kemampuan mereka dan membandingkan harga produk dari berbagai online shop yang ada serta dapat memesan suatu produk 24 jam sehari darimana saja, sehingga lebih efektif dan efisien ketimbang harus mengunjungi langsung toko tersebut yang tentunya akan memakan waktu dan tenaga.

Selain melakukan pembelian secara online itu sendiri mempunyai konsekuensi yang tinggi, tidak sedikit pula mahasiswa yang lebih suka berbelanja langsung ke toko konvensional dibandingkan melakukan pembelian secara online dikarenakan beberapa kelemahan yang terdapat pada online shop seperti, produk yang tidak bisa dilihat secara langsung, takut adanya penipuan, ketidaksesuaian produk dengan gambar, bahan maupun kualitas barang, serta pengiriman yang lama. Kenyataannya mahasiswa harus dapat melihat dan memilih online shop mana yang akan mereka pilih untuk kemudian melakukan pembelian agar terhindar dari segala bentuk penipuan saat melakukan pembelian online. Mahasiswa mempunyai kecenderungan perilaku impulsif lebih besar dari kelompok lainnya. Hal tersebut dikarenakan mahasiswa dihadapkan pada pilihan gaya hidup yang kompleks. Mahasiswa yang masih pada tahap pencarian jati diri, masih banyak meniru apa yang dilihat dan didengar melalui media sosial. Pada akhirnya mahasiswa mudah tergoda untuk melakukan belanja online guna memenuhi gaya hidupnya dan kepuasan secara emosional saat melakukan pembelian pada online shop.

\section{b. Rumusan Masalah Penelitian}

Berdasarkan latar belakang yang telah diuraikan di atas, maka masalah dalam penelitian ini adalah untuk mengetahui bagaimana pengaruh motivasi hedonis, browsing dan gaya hidup berbelanja baik secara parsial maupun simultan terhadap pembelian impulsif di online shop pada Mahasiswa Universitas Majalengka.

\section{c. Tujuan Penelitian}

Adapun tujuan penulis melakukan penelitian ini adalah untuk mengetahui pengaruh motivasi hedonis, browsing dan gaya hidup berbelanja baik secara parsial maupun simultan terhadap pembelian impulsif di online shop pada Mahasiswa Universitas Majalengka. 


\section{ENTREPRENEUR}

Jurnal Bisnis Manajemen Dan Kewirausahaan

Program Studi Manajemen Fakultas Ekonomika dan Bisnis Universitas Majalengka

Published every January and July e-ISSN : (Proses), p-ISSN: 2723-1941

Available online https://ejournal.unma.ac.id/index.php/entrepreneur

\section{KAJIAN TEORI, KERANGKA PEMIKIRAN DAN HIPOTESIS}

a. Motivasi Hedonis

Menurut ${ }^{2)}$ Christina W. Utami (2010:47) : "motivasi hedonis adalah motivasi konsumen untuk berbelanja karena berbelanja merupakan suatu kesenangan tersendiri sehingga tidak memberikan manfaat dari produk yang dibeli".

Menurut ${ }^{2)}$ Christina W. Utami (2010:49) ada beberapa indikator dalam variabel motivasi hedonis, yaitu pengalaman, sosial, suasana hati, mengikuti trend, mencari diskon.

\section{b. Browsing}

Menurut ${ }^{8}$ Tauber (1972) dalam ${ }^{6}$ Gultekin dan Ozer (2012), browsingadalah suatu sistem transportasi modern yang meningkatkan waktu luang konsumen dan dapat menghasilkan peningkatan mobilitas konsumen. Karena itu, konsumen lebih suka berbelanja pada waktu luang melalui browsing.

Menurut ${ }^{8)}$ Tauber (1972) dalam ${ }^{6}$ Gultekin dan Ozer (2012) variabel browsing dapat diukur dengan beberapa indikator duantaranya adanya diferensiasi atau perbedaan dengan toko secara fisik, adanya stimulasi sensorik, adanya interaksi sosial.

\section{c. Gaya Hidup Berbelanja}

Menurut ${ }^{9}$ Cobb dan Hoyer (1986) dalam ${ }^{7)}$ E. Japarianto dan S. Sugiharto (2011), mengungkapkan bahwa konsumen diminta untuk menunjukan sejauh mana mereka sepakat atau tidak setuju dengan pernyataan yang berkaitan dengan gaya hidup berbelanja, seperti sikap terhadap merk nasional, dirasakan pengaruh iklan, dan harga kesadaran.

Indikatornya terdiri dari tawaran iklan, model terbaru, merek terkenal, kualitas terbaik, ingin membeli merek berbeda, mencari produk yang sama dengan merek yang lain.

\section{d. Pembelian Impulsif}

Menurut ${ }^{10)}$ Bayley dan Nancarrow (1998) dalam ${ }^{11)}$ Aprilia Eka (2014), menegaskan bahwa adanya perasaanperasaan tertentu yang berhubungan dengan pembelian impulsif, seperti perasaan harus segera membeli produk, mengabaikan konsekuensi negatif, perasaan gembira, bahkan euforia, pertentangan antara kontrol hingga perasaan senang pada diri konsumen.

Menurut ${ }^{10}$ Bayley dan Nancarrow (1998) dalam ${ }^{11)}$ Aprilia Eka S. (2014) mengelompokkan pembelian impulsif menjadi empat indikator diantaranya pembelian spontan, pembelian tanpa berpikir akibat, pembelian terburu-buru, pembelian dipengaruhi keadaan emosional

\section{Kerangka Pemikiran}

Pembelian secara online sangat mempengaruhi konsumen untuk melakukan pembelian impulsif. Hal-hal yang dapat mempengaruhi pembelian impulsif adalah motivasi hedonis, browsing dan gaya hidup berbelanja terhadap pembelian impulsif. Selain itu browsing juga menjadi salah satu penyebab terjadinya pembelian impulsif. Karena itu, konsumen lebih suka berbelanja pada waktu luang melalui browsing. Gaya hidup berbelanja pun 


\section{ENTREPRENEUR}

\section{Jurnal Bisnis Manajemen Dan Kewirausahaan}

\section{Program Studi Manajemen Fakultas Ekonomika dan Bisnis Universitas Majalengka}

Published every January and July e-ISSN : (Proses), p-ISSN: 2723-1941

Available online https://ejournal.unma.ac.id/index.php/entrepreneur

menjadi penyebab terjadinya pembelian impulsif.

Maka dapat dijelaskan bahwa variabel pembelian impulsif dipengaruhi oleh berbagai jenis faktor perilaku konsumen diantaranya adalah motivasi hedonis, browsing dan gaya hidup berbelanja. Dengan adanya faktor perilaku konsumen tersebut, dapat membantu konsumen untuk melakukan pembelian impulsif.

Konsumen cenderung memilih suatu produk berdasarkan gambar produkproduk menarik yang ada pada online shop yang memicu konsumen untuk membeli barang meskipun tidak sesuai dengan kebutuhannya. Hal ini sesuai dengan penelitian yang dilakukan oleh ${ }^{4)}$ Toto Pribadi dan Winarso (2015) yang membuktikan bahwa terdapat pengaruh positif dan signifikan antara Motivasi Hedonis, Browsing dan Gaya Belanja terhadap Pembelian Impulsif.

Berdasarkan uraian kerangka pemikiran di atas, maka dapat digambarkan dalam paradigma penelitian sebagai berikut :

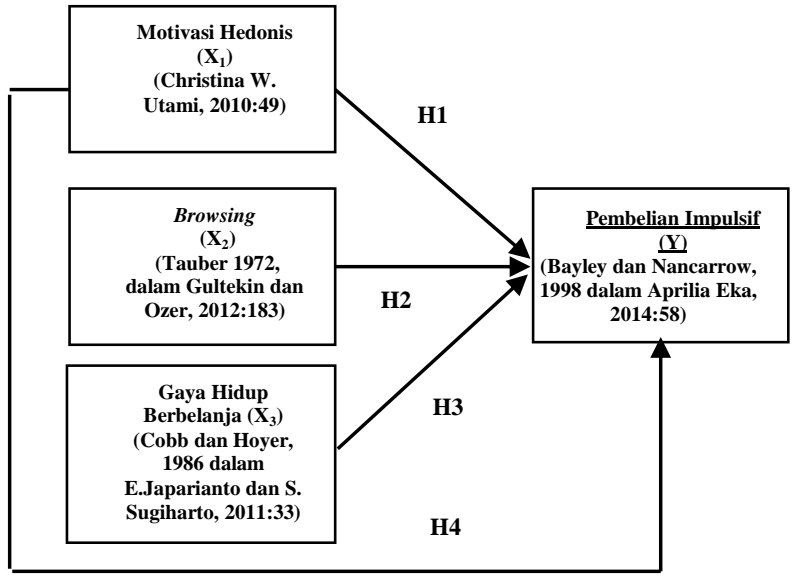

Gambar 2.1.

Paradigma Penelitian

\section{Hipotesis}

$\mathrm{H}_{1} \quad=$ Motivasi Hedonis berpengaruh terhadap Pembelian Impulsif di Online Shop.

$\mathrm{H}_{2} \quad=$ Browsing berpengaruh terhadap Pembelian Impulsif di Online Shop.

$\mathrm{H}_{3}=\underset{\text { berpengaruh }}{\text { Gaya Hidup }} \begin{array}{r}\text { Berbelanja } \\ \text { terhadap }\end{array}$
Pembelian Impulsif di Online Shop.

$\mathrm{H}_{4}=$ Motivasi Hedonis, Browsing dan Gaya Hidup Berbelanja berpengaruh terhadap Pembelian Impulsif di Online Shop.

METODE PENELITIAN 


\section{ENTREPRENEUR}

\section{Jurnal Bisnis Manajemen Dan Kewirausahaan}

Program Studi Manajemen Fakultas Ekonomika dan Bisnis Universitas Majalengka

Published every January and July e-ISSN : (Proses), p-ISSN: 2723-1941

Available online https://ejournal.unma.ac.id/index.php/entrepreneur

Metode yang digunakan dalam penelitian ini yaitu metode survey dengan teknik analisis deskriptif dan analisis verifikatif.

Variabel-variabel yang dibutuhkan dalam penelitian terdiri dari tiga variabel. Variabel independen yaitu Motivasi Hedonis, Browsing dan Gaya Hidup Berbelanja, sedangkan variabel dependen yaitu Pembelian Impusif.

a. Motivasi Hedonis $\left(\mathrm{X}_{1}\right)$

Indikator Motivasi Hedonic menurut ${ }^{2)}$ Christina W. Utami (2010:49), yaitu pengalaman, sosial, suasana hati, mengikuti trend, berbelanja untuk orang lain, dan mencari diskon.

b. Browsing $\left(\mathrm{X}_{2}\right)$

Indikatornya terdiri dari adanya diferensiasi atau perbedaan dengan toko secara fisik, adanya stimulasi sensorik, dan adanya interaksi sosial (Tauber (1972) dalam ${ }^{6)}$ Gultekin dan Ozer (2012:183). c. Gaya Hidup Berbelanja $\left(\mathrm{X}_{3}\right)$.

Indikatornya terdiri dari tawaran iklan, model terbaru, merek terkenal, kualitas terbaik, ingin membeli merek berbeda, dan mencari produk yang sama dengan merek yang lain (Cobb dan Hoyer (1986) dalam ${ }^{7)}$ E. Japrianto dan S. Sugiharto (2011:33).

d. Pembelian Impulsif (Y)

Indikatornya terdiri dari pembelian spontan, pembelian tanpa berpikir akibat, pembelian terburu-buru, dan pembelian dipengaruhi keadaan sosial ${ }^{10)}$ Baylel dan Nancarrow (1998) dalam ${ }^{11)}$ Aprilia Eka (2014:58).

Indikator-indikator tersebut diukur dengan skala penilaian Likert yang memiliki lima tingkat preferensi jawaban yang masing-masing mempunyai skor 1 5 dengan rincian sebagai berikut:

Tabel 3.1

Kriteria Penilaian Dengan Skala Likert

\begin{tabular}{|l|l|}
\hline Jawaban Pernyataan & Skor Jawaban \\
\hline Sangat Setuju & 5 \\
\hline Setuju & 4 \\
\hline Ragu-ragu & 3 \\
\hline Tidak Setuju & 2 \\
\hline Sangat Tidak Setuju & 1 \\
\hline
\end{tabular}

Sumber: ${ }^{12}$ Sugiyono, 2017:160

a. Populasi dalam penelitian ini adalah mahasiswa Universitas Majalengka yang berjumlah 5.660 mahasiswa. 


\section{ENTREPRENEUR}

\section{Jurnal Bisnis Manajemen Dan Kewirausahaan}

Program Studi Manajemen Fakultas Ekonomika dan Bisnis Universitas Majalengka

Published every January and July e-ISSN : (Proses), p-ISSN: 2723-1941

Available online https://ejournal.unma.ac.id/index.php/entrepreneur

Tabel 3.2

Jumlah Mahasiswa Universitas Majalengka Tahun 2017/2018

\begin{tabular}{|l|l|l|}
\hline No. & Fakultas & $\begin{array}{l}\text { Jumlah } \\
\text { (orang) }\end{array}$ \\
\hline 1 & Program Pascasarjana & 119 \\
2 & FISIP & 779 \\
3 & FKIP & 1.462 \\
4 & FEB & 1.284 \\
5 & FAPERTA & 578 \\
6 & F. Agama Islam & 190 \\
7 & F. Teknik & 882 \\
8 & F. Hukum & 366 \\
\hline \multicolumn{2}{|l|}{ Jumlah } & 5.660 \\
\hline
\end{tabular}

Sumber : Kementrian Riset, Teknologi dan Pendidikan Tinggi dan TU FEB

Untuk mengetahui jumlah sampel dalam penelitian ini dilakukan dengan menggunakan rumus Slovin dengan tingkat kesalahan 10\%. Maka jumlah sampel yang digunakan sebanyak 100 responden. Dari jumlah sampel tersebut kemudian ditentukan jumlah sampel untuk masing-masing Fakultas menggunakan rumus Proportionate Random Sampling dengan rasio perbandingan jumlah mahasiswa sebagai berikut :

$$
n i=\frac{N i}{N} \times n
$$

Sumber $:{ }^{12)}$ Sugiyono (2010:64)

Keterangan :

$\mathrm{n}_{\mathrm{i}}=$ Jumlah sampel

$\mathrm{n}=$ Jumlah sampel seluruhnya

$\mathrm{N}_{\mathrm{i}}=$ Jumlah populasi

$\mathrm{N}=$ Jumlah populasi seluruhnya

Tabel 3.3.

Data Responden

\begin{tabular}{|c|c|c|c|}
\hline No. & Fakultas & Populasi & Sampel \\
\hline 1. & Pascasarjana & 119 & 2 \\
\hline 2. & FISIP & 779 & 14 \\
\hline 3. & FKIP & 1.462 & 26 \\
\hline 4. & FEB & 1.284 & 23 \\
\hline 5. & FAPERTA & 578 & 10 \\
\hline 6. & FAI & 190 & 3 \\
\hline 7. & Teknik (FT) & 882 & 16 \\
\hline 8. & Hukum (FH) & 366 & 6 \\
\hline \multicolumn{2}{|r|}{ Jumlah } & 5.660 & 100 \\
\hline
\end{tabular}

Sumber : Data diolah sendiri, 2018 


\section{b. Teknik Pengumpulan Data}

Jenis data yang digunakan dalam penelitian ini adalah data kuantitatif. Sumber pengumpulan data yang didapatkan dalam penelitian ini yaitu data primer. Teknik pengumpulan data melalui kuesioner dengan cara memberikan kuesioner kepada responden yaitu Mahasiswa Universitas Majalengka untuk mendapatkan jawaban informasi yang sesungguhnya terjadi.

\section{c. Pengujian Instrumen Penelitian}

Pengujian instrument berupa uji validitas dan uji reliabilitas. Untuk menghitung validitas, penulis akan meneliti dengan menggunakan alat analisis validitas Pearson Product Moment (PPM). Pengujian reliabilitas dalam penelitian ini dilakukan dengan teknik Cronbach;s Alpha.

Data yang dikumpulkan, selain data sekunder diantaranya adalah data primer. Data yang berskala ordinal harus ditransformasikan ke dalam skala interval. Untuk merubah data yang $\mathrm{n} \quad=$ Jumlah Sampel

Maka, uji hipotesis yang dihasilkannya sebagai berikut :

Ho $: r=0$ : Tidak ada pengaruh secara signifikan

Ha : $r \neq 0$ : Ada pengaruh secara signifikan

Kaidah pengujiannya adalah :

1) Jika $t_{\text {hitung }} \geq t_{\text {tabel }}$, maka Ho ditolak dan Ha diterima.

2) Jika $t_{\text {hitung }} \leq t_{\text {tabel}}$, maka Ho diterima dan Ha ditolak

Sementara Uji Simultan (Uji F) dilakukan dengan membandingkan $\mathrm{F}_{\text {hitung }}$ berskala ordinal menjadi interval adalah dengan menggunakan Method of Successive Interval (MSI).

\section{d. Analisis Data}

Analisis data dalam penelitian ini menggunakan analisis deskriptif dan verifikatif dengan melakukan uji asumsi klasik (uji normalitas, uji multikolineritas, uji heteroskedastisitas, uji autokorelasi), serta analisis regresi linier berganda, dan koefisien determinasi.

\section{e. Uji Hipotesis}

Uji $t$ dilakukan dengan membandingkan $t_{\text {hitung }}$ dengan $t_{\text {tabel }}$ pada tingkat signifikan $\alpha 5 \%$ dengan $\mathrm{dk}=\mathrm{n}-\mathrm{k}$ dengan rumus :

$$
t_{\text {hitung }}=\frac{\sqrt{n}-2}{\sqrt{1}-r^{2}}
$$

Sumber : ${ }^{12)}$ Sugiyono (2010:63)

Keterangan :

$\mathrm{t}_{\text {hitung }}=$ Nilai $\mathrm{t}$

$\mathrm{r} \quad=$ Nilai Koefisien Korelasi

dengan $\mathrm{F}_{\text {tabel }}$ pada tingkat signifikan $\alpha 5 \%$ dengan $\mathrm{dk}=\mathrm{n}-\mathrm{k}-1$. Uji $\mathrm{F}$ dapat digunakan rumus sebagai berikut :

$$
\mathrm{F}_{\text {hitung }}=\frac{R^{2} / k}{\left(1-R^{2}\right) /(n-k 1)}
$$

Sumber : ${ }^{12}$ )Sugiyono (2010:235)

Keterangan :

$\mathrm{R}^{2} \quad=$ Koefisien korelasi ganda

$\mathrm{k}=$ Jumlah Variabel indevenden

$\mathrm{n} \quad=$ Jumlah anggota sampel

Maka kaidah pengujian adalah : 


\section{ENTREPRENEUR}

\section{Jurnal Bisnis Manajemen Dan Kewirausahaan}

Program Studi Manajemen Fakultas Ekonomika dan Bisnis Universitas Majalengka

Published every January and July e-ISSN : (Proses), p-ISSN: 2723-1941

Available online https://ejournal.unma.ac.id/index.php/entrepreneur

a) Jika nilai $\mathrm{F}_{\text {hitung }}>\mathrm{F}_{\text {tabel}}$, maka Ho diterima dan Ha ditolak. b) Jika nilai $\mathrm{F}_{\text {hitung }}<\mathrm{F}_{\text {tabel}}$, maka Ho diterima dan Ha ditolak.

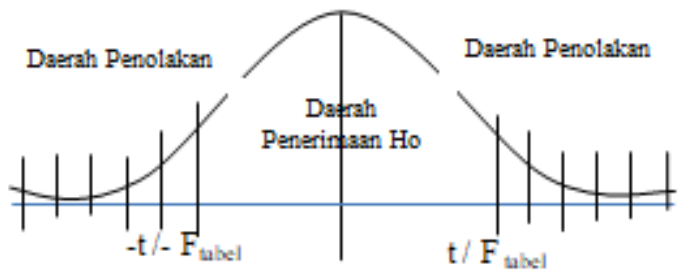

Gambar 3.1.

\section{Kurva Uji Dua Pihak}

\section{IV.HASIL PENELITIAN DAN PEMBAHASAN \\ a. Analisis Deskriptif}

Berdasakan data hasil kuesioner yang terdiri dari 6 pernyataan untuk variabel motivasi hedonis $\left(\mathrm{X}_{1}\right)$, diperoleh total skor sebesar 2.326 hal ini menunjukan bahwa hasil penelitian mengenai motivasi hedonis pada mahasiswa Universitas Majalengka yang melakukan pembelanjaan pada online shop berada pada kriteria tinggi.

Berdasakan data hasil kuesioner yang terdiri dari 3 pernyataan untuk variabel browsing $\left(\mathrm{X}_{2}\right)$, diperoleh total skor sebesar 1.166 hal ini menunjukan bahwa hasil penelitian mengenai browsing pada mahasiswa Universitas Majalengka yang melakukan pembelanjaan pada online shop berada pada kriteria tinggi.

Berdasakan data hasil kuesioner yang terdiri dari 6 pernyataan untuk variabel gaya hidup berbelanja $\left(\mathrm{X}_{3}\right)$, diperoleh total skor sebesar 2.336 hal ini menunjukan bahwa hasil penelitian mengenai gaya hidup berbelanja pada mahasiswa Universitas Majalengka yang melakukan pembelanjaan pada online shop berada pada kriteria tinggi.

Berdasakan data hasil kuesioner yang terdiri dari 5 pernyataan untuk variabel pembelian impulsif (Y), diperoleh total skor sebesar 1.924 hal ini menunjukan bahwa hasil penelitian mengenai pembelian impulsif pada mahasiswa Universitas Majalengka yang melakukan pembelanjaan pada online shop berada pada kriteria tinggi.

\section{b. Analisis Verifikatif}

\section{Uji Normalitas}

Hasil uji normalitas data dari penelitian dapat dilihat pada tabel di bawah ini : 


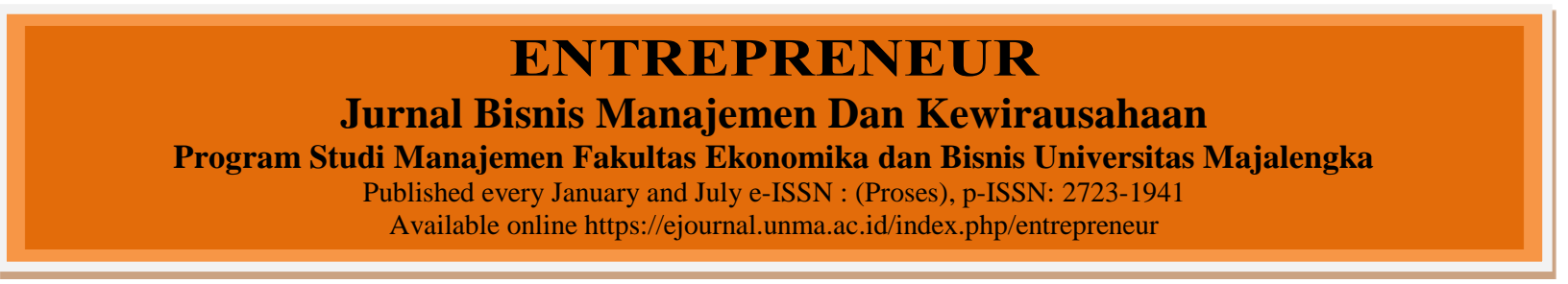

Tabel 4.1

One-Sample Kolmogorov-Smirnov Test

\begin{tabular}{|c|c|c|}
\hline & & $\begin{array}{l}\text { Unstandard } \\
\text { ized } \\
\text { Residual }\end{array}$ \\
\hline $\mathrm{N}$ & & 100 \\
\hline Normal & Mean & ,0000000 \\
\hline Parameters $^{\mathrm{a}}$ & Std. & 2,81154400 \\
\hline Extreme & Absolute & 107 \\
\hline Differences & $\begin{array}{l}\text { Positive } \\
\text { Negative }\end{array}$ & $\begin{array}{l}, 086 \\
-.107\end{array}$ \\
\hline $\begin{array}{l}\text { Kolmogorov-Smirr } \\
\text { Asymp. Sig. (2-tail }\end{array}$ & $\begin{array}{l}\text { nov Z } \\
\text { led) }\end{array}$ & $\begin{array}{l}1,073 \\
, 200\end{array}$ \\
\hline
\end{tabular}

a. Test distribution is Normal.

Berdasarkan tabel 4.1 di atas dapat diketahui bahwa K-S sebesar 1,073 dengan taraf signifikan (Asymp. Sig. (2tailed) adalah 0,200 menunjukan signifikan yang lebih besar dari $\alpha=0,05$. Sehingga dapat disimpulkan bahwa data dalam penelitian tersebut berdistribusi normal.

\section{a. Uji Validitas}

Berdasarkan hasil uji validitas terhadap variabel Motivasi Hedonis $\left(\mathrm{X}_{1}\right)$ menunjukkan hasil bahwa $r_{\text {hitung }}$ untuk 6 pernyataan lebih besar dari $r_{\text {tabel }}$ pada taraf signifikan 5\% yakni sebesar 0,195. Sehingga dapat disimpulkan bahwa seluruh butir pernyataan tersebut valid. Variabel Browsing $\left(\mathrm{X}_{2}\right)$ menunjukkan bahwa $r_{\text {hitung }}$ untuk 3 pernyataan lebih besar dari $r_{\text {tabel }}$ pada taraf signifikan 5\% yakni sebesar 0,195. Sehingga dapat disimpulkan bahwa seluruh butir pernyataan tersebut valid. Variabel Gaya
Hidup Berbelanja $\left(\mathrm{X}_{3}\right)$ menunjukkan bahwa $r_{\text {hitung }}$ untuk 6 pernyataan lebih besar dari $r_{\text {tabel }}$ pada taraf signifikan 5\% yakni sebesar 0,195. Sehingga dapat disimpulkan bahwa seluruh butir pernyataan tersebut valid. Variabel Pembelian Impulsif (Y) menunjukkan bahwa $r_{\text {hitung }}$ untuk 5 pernyataan lebih besar dari $r_{\text {tabel }}$ pada taraf signifikan 5\% yakni sebesar 0,195. Sehingga dapat disimpulkan bahwa seluruh butir pernyataan tersebut valid.

\section{b. Uji Reliabilitas}

Untuk Uji Reliabilitas dikatakandan reliable apabila nilai Cronbach's Alpha lebih besar dari 0,60. Hasil uji reliabilitas pada masing-masing variabel menunjukkan nilai Cronbach's Alpha yang lebih besar dibandingkan dengan nilai kritis, yakni $(0,655),(0,691),(0,775)$ dan $(0,741)$ lebih besar dari 0,60 . Ini 


\section{ENTREPRENEUR}

\section{Jurnal Bisnis Manajemen Dan Kewirausahaan}

Program Studi Manajemen Fakultas Ekonomika dan Bisnis Universitas Majalengka

Published every January and July e-ISSN : (Proses), p-ISSN: 2723-1941

Available online https://ejournal.unma.ac.id/index.php/entrepreneur

berarti bahwa seluruh pernyataan dalam kuesioner dinyatakan reliable.

\section{c. Uji Asumsi Klasik}

Uji normalitas data dalam penelitian ini dilakukan dengan uji kolmogrovsmirnov dan grafik histogram. Hasil uji normalitas data dalam penelitian ini dapat diketahui bahwa K-S sebesar 1,073 dengan taraf signifikan (Asymp. Sig. (2tailed) adalah 0,200 menunjukan signifikan yang lebih besar dari $\alpha=0,05$. Sehingga dapat disimpulkan bahwa data dalam penelitian tersebut berdistribusi normal.
Berdasarkan hasil pengujian, maka dapat diketahui bahwa Motivasi Hedonis dengan nilai VIF sebesar 1,377 < 10 dan hasil perhitungan nilai Tolerance sebesar 0,726>0,10, Browsing dengan nilai VIF sebesar 1,009 < 10 dan hasil perhitungan nilai Tolerance sebesar 0,991 >0,10, dan Gaya Hidup Berbelanja dengan nilai VIF sebesar $1,378<10$ dan hasil perhitungan nilai Tolerance sebesar $0,726>0,10$. Sehingga dapat disimpulkan bahwa tidak ada multikoleniaritas antar variabel independen dalam model regresi maka variabel dapat digunakan dalam penelitian.

\section{d. Uji Multikolinearitas}

Tabel 4.2

\section{Coefficients $^{\mathrm{a}}$}

\begin{tabular}{|c|c|c|c|c|c|c|c|c|c|c|}
\hline \multirow[b]{2}{*}{ Model } & \multicolumn{2}{|c|}{$\begin{array}{l}\text { Unstandardi } \\
\text { zed } \\
\text { Coefficients }\end{array}$} & \multirow{2}{*}{\begin{tabular}{|l|}
$\begin{array}{l}\text { Standar } \\
\text { dized }\end{array}$ \\
Coeffici \\
ents \\
\\
Beta \\
\end{tabular}} & \multirow[b]{2}{*}{$\mathrm{T}$} & \multirow[b]{2}{*}{ Sig. } & \multicolumn{3}{|c|}{ Correlations } & \multicolumn{2}{|c|}{$\begin{array}{l}\text { Collinearity } \\
\text { Statistics }\end{array}$} \\
\hline & B & $\begin{array}{l}\text { Std. } \\
\text { Error }\end{array}$ & & & & $\begin{array}{l}\text { Zero- } \\
\text { order }\end{array}$ & $\begin{array}{l}\text { Part } \\
\text { ial }\end{array}$ & Part & $\begin{array}{l}\text { Tolera } \\
\text { nce }\end{array}$ & VIF \\
\hline 1 (Constant) & $\begin{array}{l}3,38 \\
0\end{array}$ & 2,074 & & 1,630 & , 106 & & & & & \\
\hline $\begin{array}{l}\text { Motivasi } \\
\text { Hedonis }\end{array}$ &, 304 &, 100 & ,276 & 3,047 & ,003 & ,403 & ,297 & ,236 & ,726 & 1,377 \\
\hline $\begin{array}{l}\text { Browsing } \\
\text { Gava }\end{array}$ &, 812 &, 130 &, 487 & 6,271 &, 000 &, 522 &, 539 & ,485 & ,991 & 1,009 \\
\hline $\begin{array}{l}\text { Hidup } \\
\text { Berbelanja }\end{array}$ &, 167 & 089 &, 171 & 1,985 & 043 &, 355 &, 189 &, 145 & ,726 & 1,378 \\
\hline
\end{tabular}

a. Dependent Variable:

Pembelian Impulsif 


\section{ENTREPRENEUR}

Jurnal Bisnis Manajemen Dan Kewirausahaan

Program Studi Manajemen Fakultas Ekonomika dan Bisnis Universitas Majalengka

Published every January and July e-ISSN : (Proses), p-ISSN: 2723-1941

Available online https://ejournal.unma.ac.id/index.php/entrepreneur

\section{e. Uji Heteroskedastisitas}

Scatterplot

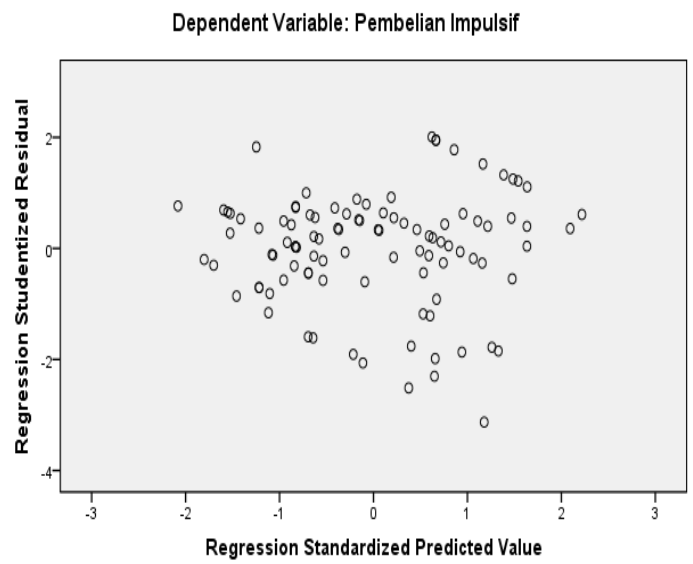

Berdasarkan pada grafik Scatterplot dapat dilihat bahwa terdapat pola yang jelas serta titik-titik yang menyebar di atas dan di bawah angka 0 dan pada sumbu Y. Maka dapat disimpulkan bahwa tidak terjadi heteroskedastisitas pada model regresi yang digunakan, sehingga layak dipakai untuk memprediksi pembelian impulsif berdasarkan masukan variabel independen motivasi hedonis, browsing dan gaya hidup berbelanja.

\section{f. Uji Autokorelasi}

Berdasarkan hasil analisis data, maka dapat diketahui nilai d (Durbin-Watson $)=$ 1,929. Selanjutnya bandingkan nilai ini dengan nilai tabel signifikan 0,05\%, jumlah sampel $(n)=100$ dan variabel independen $(\mathrm{k})=3$, maka diperoleh nilai $\mathrm{dU}=1,7364$ (terdapat pada tabel DurbinWatson). Berdasarkan tabel dasar pengambilan keputusan aoutokorelasi, maka persamaan yang sesuai dengan penelitian ini yaitu $1,7364<1,929<$ 2,2636 (4 - 1,7364). Sehingga dapat disimpulkan bahwa dasar keputusannya tidak ditolak, artinya tidak terdapat autokorelasi baik itu positif maupun negatif.

\section{Analisis Regresi Linier Berganda}

Berdasarkan pengolahan data, maka hasil uji persamaan model regresi linier berganda ini dapat dituliskan sebagai berikut :

$$
\mathrm{Y}=3,380+0,304_{\mathrm{X} 1}+0,812_{\mathrm{X} 2}+0,167_{\mathrm{X} 3}+\varepsilon
$$

\section{Uji Koefisien Determinasi $\left(\mathbf{R}^{\mathbf{2}}\right)$}

Pengaruh motivasi hedonis terhadap pembelian impulsif diperoleh nilai $\mathrm{R}^{\mathrm{a}}$ sebesar $(0,403)^{2}$ x $100 \%=16,24(\mathrm{R}$ Square) Dengan demikian dapat diketahui besarnya pengaruh motivasi hedonis terhadap pembelian impulsive di online shop adalah $16,24 \%$. 


\section{ENTREPRENEUR}

\section{Jurnal Bisnis Manajemen Dan Kewirausahaan}

Program Studi Manajemen Fakultas Ekonomika dan Bisnis Universitas Majalengka

Published every January and July e-ISSN : (Proses), p-ISSN: 2723-1941

Available online https://ejournal.unma.ac.id/index.php/entrepreneur

Pengaruh browsing terhadap pembelian impulsive diperoleh nilai $\mathrm{R}^{\mathrm{a}}$ sebesar $(0,522)^{2} \times 100 \%=27,25 \%(\mathrm{R}$ Square) Dengan demikian dapat diketahui besarnya pengaruh browsing terhadap pembelian impulsif adalah $27,25 \%$.

Pengaruh gaya hidup berbelanja terhadap pembelian impulsive diperoleh nilai $\mathrm{R}^{\mathrm{a}}$ sebesar $(0,355)^{2} \times 100 \%=$ $12,60 \%$ (R Square) Dengan demikian dapat diketahui besarnya pengaruh browsing terhadap pembelian impulsif adalah $12,60 \%$.

Pengaruh gaya hidup berbelanja terhadap pembelian impulsif. Berdasarkan perhitungan dengan menggunakan SPSS, diperoleh nilai $\mathrm{R}^{\mathrm{a}}$ sebesar 0,4264 atau $42,64 \%$ menunjukan bahwa besarnya sumbangan atau kontribusi motivasi hedonis, browsing dan gaya hidup berbelanja terhadap pembelian impulsif di online shop adalah $42,64 \%$ sisanya $57,36 \%$ dipengaruhi oleh faktor lain di luar variabel yang diteliti.

\section{Uji Parsial (Uji t)}

Pengujian hipotesis dalam penelitian ini akan menggunakan alat ukur yakni uji $t$ dan uji f dengan menggunakan aplikasi SPSS versi 22. Maka Uji Parsial (uji t) yaitu dapat dilihat pada tabel coefficients berikut:

Tabel. 4.3

Coefficients

\begin{tabular}{|c|c|c|c|c|c|}
\hline \multirow[b]{2}{*}{ Model } & \multicolumn{2}{|c|}{$\begin{array}{l}\text { Unstandardized } \\
\text { Coefficients }\end{array}$} & \multirow{2}{*}{$\begin{array}{l}\text { Standardized } \\
\text { Coefficients } \\
\text { Beta }\end{array}$} & \multirow[b]{2}{*}{$\mathrm{T}$} & \multirow[b]{2}{*}{ Sig. } \\
\hline & $\mathrm{B}$ & Std. Error & & & \\
\hline (Constant) & 3,380 & 2,074 & & 1,630 & ,106 \\
\hline Motivasi Hedonis & ,304 & , 100 & ,276 & 3,047 & ,003 \\
\hline Browsing & ,812 & ,130 & 487 & 6,271 & ,000 \\
\hline Gaya Hidup Berbelanja & ,167 & ,089 & ,171 & 1,985 & ,043 \\
\hline
\end{tabular}

Dilihat dari tabel 4.3. pada variabel motivasi hedonis diperoleh nilai $t_{\text {hitung }}$ sebesar 3,047 bertanda positif dengan signifikan sebesar 0,003. Pada derajat bebas $(\mathrm{dk})=\mathrm{n}-\mathrm{k}=100-3=97$ dengan $\alpha$ $=5 \%$. Pada tabel distribusi $\mathrm{t}$ untuk $\mathrm{dk}=$ 97 adalah 1,984. Maka diperoleh $t_{\text {hitung }}$ sebesar 3,047 dan $t_{\text {tabel }}$ sebesar 1,984 dengan taraf signifikan sebesar 0,003.

Karena nilai $\mathrm{t}_{\text {hitung }} 3,047>\mathrm{t}_{\text {tabel }} 1,984$ dan nilai signifikannya $0,003<0,05$, maka Ho ditolak, sehingga hipotesis pertama yang menyatakan bahwa terdapat pengaruh secara signifikan motivasi hedonis terhadap pembelian impulsif dapat dibuktikan kebenarannya.

Dilihat dari tabel 4.3. pada variabel browsing diperoleh nilai $t_{\text {hitung }}$ sebesar 6,271 bertanda positif dengan signifikan sebesar 0,000 . Pada derajat bebas $(\mathrm{dk})=\mathrm{n}$ $-\mathrm{k}=100-3=97$ dengan $\alpha=5 \%$. Pada tabel distribusi $\mathrm{t}$ untuk $\mathrm{dk}=97$ adalah 


\section{ENTREPRENEUR}

Jurnal Bisnis Manajemen Dan Kewirausahaan

Program Studi Manajemen Fakultas Ekonomika dan Bisnis Universitas Majalengka

Published every January and July e-ISSN : (Proses), p-ISSN: 2723-1941

Available online https://ejournal.unma.ac.id/index.php/entrepreneur

1,984 (untuk tabel distribusi $\mathrm{t}$ dapat dilihat di lampiran).

Maka diperoleh $t_{\text {hitung }}$ sebesar 6,271 dan $\mathrm{t}_{\text {tabel }}$ sebesar 1,984 dengan taraf signifikan

sebesar 0,000. Karena nilai thitung 6,271> $\mathrm{t}_{\text {tabel } 1,984 \text { dan nilai signifikannya } 0,000<}^{<}$ 0,05 , maka Ho ditolak, sehingga hipotesis kedua yang menyatakan bahwa terdapat pengaruh secara signifikan browsing terhadap pembelian impulsif dapat dibuktikan kebenarannya.

Dilihat dari tabel 4.3. pada variabel gaya hidup berbelanja diperoleh nilai $\mathrm{t}_{\text {hitung }}$ sebesar 1,985 bertanda positif dengan signifikan sebesar 0,043. Pada derajat bebas $(\mathrm{dk})=\mathrm{n}-\mathrm{k}=100-3=97$ dengan $\alpha=5 \%$. Pada tabel distribusi $\mathrm{t}$ untuk $\mathrm{dk}=97$ adalah 1,984 (untuk tabel distribusi t dapat dilihat di lampiran). Maka diperoleh $t_{\text {hitung }}$ sebesar 1,985 dan $\mathrm{t}_{\text {tabel }}$ sebesar 1,984 dengan taraf signifikan sebesar 0,043 . Karena nilai $t_{\text {hitung }} 1,985>$ $\mathrm{t}_{\text {tabel }} 1,984$ dan nilai signifikannya $0,043<$ 0,05, maka Ho ditolak, sehingga hipotesis ketiga yang menyatakan bahwa terdapat pengaruh secara signifikan gaya hidup berbelanja terhadap pembelian impulsif dapat dibuktikan kebenarannya.

\section{Uji Simultan (Uji F)}

Tabel 4.4

ANOVA $^{\mathrm{b}}$

\begin{tabular}{|l|l|l|l|l|l|}
\hline Model & Sum of Squares & Df & Mean Square & F & Sig. \\
\hline 1 Regression & 581,937 & 3 & 193,979 & 23,796 &, $000^{\mathrm{a}}$ \\
Residual & 782,573 & 96 & 8,152 & & \\
Total & 1364,510 & 99 & & & \\
\hline
\end{tabular}

a. Predictors: (Constant), Gaya Hidup Berbelanja, Browsing, Motivasi Hedonis

b. Dependent Variable: Pembelian Impulsif

Berdasarkan perhitungan uji $\mathrm{F}$ diperoleh nilai profitabilitas (sig) $=0,000$, sedangkan nilai $\mathrm{F}_{\text {tabel }}$ pada taraf signifikan $5 \%(\mathrm{dk})=\mathrm{n}-\mathrm{k}-1=100-3-1=96$. Pada tabel distribusi $\mathrm{F}$ untuk $\mathrm{dk}=96$ adalah 3,09 (untuk tabel distribusi F dapat dilihat dari lampiran).

Dari perhitungan di atas, maka diperoleh $\mathrm{F}_{\text {tabel }}$ sebesar 3,09 karena $\mathrm{F}_{\text {hitung }}$ $=23,796>\mathrm{F}_{\text {tabel }}=3,09$ maka Ho ditolak, sehingga hipotesis keempat yang menyatakan bahwa terdapat pengaruh secara signifikan antara motivasi hedonis, browsing dan gaya hidup berbelanja terhadap pembelian impulsif dapat dibuktikan kebenarannya.

\section{Pembahasan}

1. Pengaruh Motivasi Hedonis Terhadap Pembelian Impulsif di Online Shop Pada Mahasiswa Universitas Majalengka

Berdasarkan hasil analisis verifikatif, menyatakan bahwa variabel motivasi hedonis berpengaruh positif terhadap pembelian impulsif. Hal ini dibuktikan dengan nilai koefisien determinasi yang menunjukan besarnya pengaruh motivasi 


\section{ENTREPRENEUR}

Jurnal Bisnis Manajemen Dan Kewirausahaan

Program Studi Manajemen Fakultas Ekonomika dan Bisnis Universitas Majalengka

Published every January and July e-ISSN : (Proses), p-ISSN: 2723-1941

Available online https://ejournal.unma.ac.id/index.php/entrepreneur

hedonis terhadap pembelian impulsif sebesar $16,24 \%$. Berdasarkan hasil uji $\mathrm{t}$ variabel motivasi hedonis memiliki nilai $t_{\text {hitung }} 3,047>t_{\text {tabel }} 1,984$ dan nilai signifikannya $0,003<0,05$, maka Ho ditolak, sehingga hipotesis pertama yang menyatakan bahwa terdapat pengaruh secara signifikan motivasi hedonis terhadap pembelian impulsif dapat dibuktikan kebenarannya. Karena motivasi hedonis yang merupakan salah satu dorongan dalam diri konsumen untuk melakukan pembelian pada online shop berpengaruh terhadap pembelian impulsif. Maka motivasi hedonis merupakan faktor pendorong terjadinya pembelian impulsif.

Hasil penelitian ini konsisten dengan penelitian yang dilakukan oleh Toto Pribadi Sampurno dan Winarso (2015) yang menunjukan bahwa motivasi hedonis berpengaruh positif dan signifikan terhadap pembelian impulsif.

\section{Pengaruh Browsing Terhadap Pembelian Impulsif di Online Shop Pada Mahasiswa Universitas Majalengka}

Berdasarkan hasil analisis verifikatif, menyatakan bahwa variabel browsing berpengaruh signifikan terhadap pembelian impulsif. Hal ini dibuktikan dengan nilai koefisien determinasi yang menunjukan besarnya pengaruh browsing terhadap pembelian impulsif sebesar $27,25 \%$. Berdasarkan hasil uji t variabel browsing memiliki nilai $t_{\text {hitung }} 6,271>\mathrm{t}_{\text {tabel }}$ 1,984 dan nilai signifikannya $0,000<$ 0,05, maka Ho ditolak, sehingga hipotesis kedua yang menyatakan bahwa terdapat pengaruh secara signifikan browsing terhadap pembelian impulsif dapat dibuktikan kebenarannya. Karena browsing yang merupakan salah satu cara konsumen untuk mencari informasi dan referensi produk pada online shop berpengaruh terhadap pembelian impulsif. Maka browsing merupakan faktor pendorong terjadinya pembelian impulsif.

Hasil penelitian ini konsisten dengan penelitian yang dilakukan oleh Toto Pribadi dan Winarso (2015) yang menunjukkan bahwa terdapat pengaruh positif dan signifikan Browsing terhadap Pembelian Impulsif.

\section{Pengaruh Gaya Hidup Berbelanja Terhadap Pembelian Impulsif di Online Shop Pada Mahasiswa Universitas Majalengka}

Berdasarkan hasil analisis verifikatif, menyatakan bahwa variabel gaya hidup berbelanja berpengaruh positif terhadap pembelian impulsif. Hal ini dibuktikan dengan nilai koefisien determinasi yang menunjukan besarnya pengaruh gaya hidup berbelanja terhadap pembelian impulsif sebesar 12,60\%. Berdasarkan hasil uji $\mathrm{t}$ variabel gaya hidup berbelanja memiliki nilai $t_{\text {hitung }} 1,985>t_{\text {tabel }} 1,984$ dan nilai signifikannya $0,043<0,05$, maka Ho ditolak, sehingga hipotesis ketiga yang menyatakan bahwa terdapat pengaruh secara signifikan gaya hidup berbelanja terhadap pembelian impulsif dapat dibuktikan kebenarannya. Karena gaya hidup berbelanja yang merupakan salah satu cara konsumen menghabiskan uang dan waktu mereka untuk melakukan pembelian pada online shop berpengaruh terhadap pembelian impulsif. Maka gaya 


\section{ENTREPRENEUR}

\section{Jurnal Bisnis Manajemen Dan Kewirausahaan}

Program Studi Manajemen Fakultas Ekonomika dan Bisnis Universitas Majalengka

Published every January and July e-ISSN : (Proses), p-ISSN: 2723-1941

Available online https://ejournal.unma.ac.id/index.php/entrepreneur

hidup berbelanja merupakan faktor pendorong terjadinya pembelian impulsif.

Hasil penelitian ini konsisten dengan penelitian yang dilakukan oleh Toto Pribadi Sampurno dan Winarso (2015) yang menunjukan bahwa gaya hidup berbelanja berpengaruh positif dan signifikan terhadap pembelian impulsif.

\section{Pengaruh Motivasi Hedonis, Browsing dan Gaya Hidup} Berbelanja Terhadap Pembelian Impulsif di Online Shop Pada Mahasiswa Universitas Majalengka

Berdasarkan hasil analisis verifikatif menyatakan bahwa motivasi hedonis, browsing dan gaya hidup berbelanja berpengaruh positif terhadap pembelian impulsif. Hal ini juga dibuktikan dengan nilai koefisien determinasi yang menunjukan pengaruh motivasi hedonis, browsing dan gaya hidup berbelanja terhadap pembelian impulsif sebesar $42,64 \%$, sisanya $57,36 \%$ dipengaruhi oleh faktor lain yang tidak diteliti.
Berdasarkan hasil uji $\mathrm{F}$ diperoleh $F_{\text {tabel }}$ sebesar 3,09 karena $F_{\text {hitung }}=23,796$ $>\mathrm{F}_{\text {tabel }}=3,09$ maka Ho ditolak, sehingga hipotesis keempat yang menyatakan bahwa terdapat pengaruh secara signifikan antara motivasi hedonis, browsing dan gaya hidup berbelanja terhadap pembelian impulsif dapat dibuktikan kebenarannya. Maka, motivasi hedonis, browsing dan gaya hidup berbelanja secara bersama-sama dapat menjadi faktor pendorong terjadinya pembelian impulsif di online shop.

Hasil penelitian ini konsisten dengan penelitian yang dilakukan oleh Toto Pribadi dan Winarso (2015) yang menyatakan bahwa terdapat pengaruh positif dan signifikan antara motivasi hedonis, browsing dan gaya hidup berbelanja terhadap pembelian impulsif.

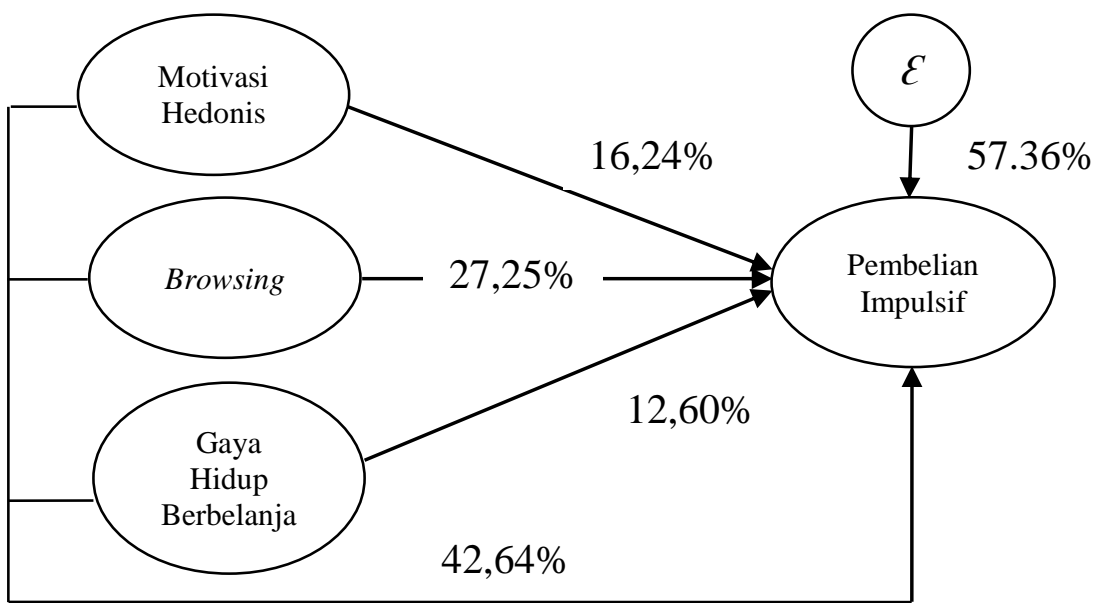

Gambar 4.1

Hasil Penelitian Antar Variabel Motivasi Hedonis, Browsing dan Gaya Hidup Berbelanja Terhadap Pembelian Impulsif 


\section{ENTREPRENEUR}

Jurnal Bisnis Manajemen Dan Kewirausahaan

Program Studi Manajemen Fakultas Ekonomika dan Bisnis Universitas Majalengka

Published every January and July e-ISSN : (Proses), p-ISSN: 2723-1941

Available online https://ejournal.unma.ac.id/index.php/entrepreneur

\section{KESIMPULAN DAN IMPLIKASI}

Berdasarkan hasil penelitian dan analisis data yang telah dilakukan di Universitas Majalengka mengenai motivasi hedonis, browsing dan gaya hidup berbelanja terhadap pembelian impulsif pada online shop, maka penulis mengambil kesimpulan sebagai berikut :

1. Motivasi hedonis berpengaruh positif dan signifikan terhadap pembelian impulsif. Artinya, semakin tinggi tingkat motivasi hedonis maka akan semakin tinggi pula tingkat pembelian impulsif di online shop.

2. Browsing berpengaruh positif dan signifikan terhadap pembelian impulsif. Artinya, semakin tinggi browsing maka akan semakin tinggi pula tingkat pembelin impulsif di online shop.

3. Gaya hidup berbelanja berpengaruh positif dan signifikan terhadap pembelian impulsif. Artinya, semakin tinggi tingkat gaya hidup berbelanja konsumen maka akan semakin tinggi pula tingkat pembelian impulsif di online shop.

4. Secara simultan motivasi hedonis, browsing dan gaya hidup berbelanja berpengaruh positif dan signifikan terhadap pembelian impulsif. Artinya, semakin tinggi tingkat motivasi hedonis, browsing dan gaya hidup berbelanja maka akan semakin tinggi tingkat pembelian impulsif konsumen pada online shop.

\section{a. Saran}

Berdasarkan hasil penelitian dan pembahasan yang telah dilakukan, maka penulis memberikan saran yang diharapkan dapat memberikan manfaat dan dijadikan bahan pertimbangan bagi pihak-pihak yang berkepentingan, sebagai berikut :

1. Motivasi hedonis di online shop termasuk dalam kategori tinggi, akan tetapi berdasarkan hasil rekapitulasi terdapat pernyataan yang memiliki skor terendah. Oleh karena itu, pihak online shop senantiasa melakukan evaluasi terhadap pernyataan yang memiliki skor terendah seperti untuk dapat membuat konsumen tertarik berbelanja untuk orang lain penjual dapat menjual produk- produk dengan sistem paket (dua atau lebih produk dalam satu paket dengan harga normal atau lebih murah). Dengan begitu, penjual di online shop dapat meningkatkan pembelian konsumen pada online shop.

2. Browsing di online shop termasuk dalam kategori tinggi, akan tetapi berdasarkan hasil rekapitulasi terdapat pernyataan yang memiliki skor terendah. Oleh karena itu, pihak online shop senantiasa melakukan evaluasi terhadap pernyataan yang memiliki skor terendah seperti untuk membuat konsumen memiliki interaksi yang baik saat berbelanja, penjual dapat memberikan deskripsi yang lengkap pada produk-produk yang dijualnya seperti ukuran barang, warna, bahan dan kegunaannya. 
3. Gaya hidup berbelanja di online shop termasuk dalam kategori tinggi, akan tetapi berdasarkan hasil rekapitulasi terdapat pernyataan yang memiliki skor terendah. Oleh karena itu, pihak online shop senantiasa melakukan evaluasi terhadap pernyataan yang memiliki skor terendah seperti untuk membuat konsumen membeli produk merek terkenal, penjual bisa lebih selektif dalam menentukan produk yang akan dipasarkan kepada konsumen tanpa mengesampingkan kegunaan dari produk yang dijual.

4. Pembelian impulsif di online shop termasuk dalam kategori tinggi, akan tetapi berdasarkan hasil rekapitulasi terdapat pernyataan yang memiliki skor terendah. Oleh karena itu, untuk membuat konsumen membeli produk di online shop penjual harus dapat menstimulasi konsumen dalam melakukan pembelian secara impulsif (tanpa perencanaan terlebih dahulu) dengan cara penjual di online shop dapat memasarkan produk-produk yang lebih dibutuhkan banyak konsumen dan memiliki kualitas baik dengan harga yang terjangkau.

\section{DAFTAR PUSTAKA}

1. Teknologi.id. 2018. E-Commerce dengan Pengunjung Terbanyak di Indonesia. Diperoleh dari : https://teknologi.id/bisnis/ecommerce-dengan-pengunjungterbanyak-di-indonesial
2. Christina W. Utami. 2010. Manajemen Ritel Strategi dan Implementasi Operasional Bisnis Ritel Modern di Indonesia. Jagakarsa : Salemba Empat.

3. Dayang A. Kosyu, Kadarisman Hidayat dan Yusri Abdilah. 2014. Pengaruh Hedonis Shopping Motifes Terhadap Shopping Lifestyle dan Impulse Buying. Jurnal Administrasi Bisnis (JAB). Vol. 14. No. 2. Hal: 17.

4. Toto Pribadi Sampurno dan Winarso. 2015. Pengaruh Motivasi Hedonis, Browsing dan Gaya Belanja Terhadap Pembelian Impulsif Pada Toko Online Shop. Jurnal Manajemen Bisnis, Vol. 6 No. 1. pp 255-270.

5. Iyer. E. 1989. Unplanned Purchasing Knowledge of Shopping Environment and Time Pressure. Journal of Retailing. Vol. 65 No. 1.pp. 40-58

6. Gultekin, B., dan Ozer, L. 2012. The Influence of Hedonic Motifes and Browsing on Impulse Buying. Journal of Economics and Behavioral Studies. Vol. 4. No. 3, pp : 180-189. Maret. ISSN : 2220-6140.

7. E. Japarianto dan S. Sugiharto. 2011. Pengaruh Shopping Lifestyle dan Fashion Involvement Terhadap Impulse Buying Behavior Masyarakat High Income Surabaya. Jurnal Manajemen Pemasaran. Vol. 6. No.1. April : pp 32-41. 


\section{ENTREPRENEUR}

\section{Jurnal Bisnis Manajemen Dan Kewirausahaan}

Program Studi Manajemen Fakultas Ekonomika dan Bisnis Universitas Majalengka

Published every January and July e-ISSN : (Proses), p-ISSN: 2723-1941

Available online https://ejournal.unma.ac.id/index.php/entrepreneur

8. Tauber , E.M. 1972. “Why Do People Shop?". Journal of Marketing. Vol. 36, pp. 46-59

9. Cobb, C.J dan Hoyer, W.D. 1986. A Planned Versus Impulse Purchase Behaviour. Journal of Retailing. Vol. 62 (4), pp. 384-409
10. Geoff Bayley, Clive Nancarrow. 1998. Impulse Purchasing: A Qualitative Exploration of The Phenomenon. Books \& Case Studies. ISNN : 1352-2752. Vol. 1. No. 2, pp. 99-114

11. Aprilia Eka Sari. 2014. Analisis Faktor Yang Mempengaruhi Pembelian Spontan. Jurnal Sains Pemasaran Indonesia. Vol. XIII. No. 1 , pp : 55-73.

12. Sugiyono. 2010. Metode Penelitian Bisnis. Bandung : Alfabeta. 